\title{
Stenotrophomonas maltophilia, Bakteri Resisten Merkuri pada Limbah Pertambangan Logam
}

\author{
Mangihot Tua Gultom ${ }^{1 *}$, Shienen Sisilia ${ }^{1}$, Mariana Wahjudi ${ }^{1}$ \\ ${ }^{1}$ Fakultas Teknobiologi, Universitas Surabaya, Surabaya-Indonesia \\ * corresponding author: ihot_gultom@staff.ubaya.ac.id
}

\begin{abstract}
Mercuric-resistant bacterium isolate coded 22 was previously obtained from metal mining (tailing) wastewater samples. From the total 24 bacteria which had been isolated, isolate 22 exhibited the highest resistance toward high concentration of $\mathrm{Hg}$. In this paper it is reported results of $16 \mathrm{~S}$ rDNA-based identification of isolate 22 as well as its growth and resistance characteristics when growing on Mercuric containing Nutrient Broth medium. Isolate 22 is closely related to the bacterium, Stenotrophomonas maltophilia (identity $99 \%$ and query covered $90 \%$ ). Isolate 22 grew very well in the NB-Hg medium containing $\mathrm{Hg}$ concentration of 50 and $100 \mathrm{ppm}$. Increasing $\mathrm{Hg}$ concentration clearly lengthened lag phase although cell quantity (culture turbidity, OD600) at the initial phase were the same.
\end{abstract}

Keywords: isolate22, $\mathrm{Hg}$, identification, sequencing, $16 \mathrm{~S}$ rRNA gene

\begin{abstract}
Abstrak-Isolat 22 adalah kode isolat bakteri resisten logam Merkuri (Hg) yang didapatkan pada sampel air limbah pertambangan logam (tailing). Isolat 22 adalah isolat yang paling berdaya tahan tinggi terhadap $\mathrm{Hg}$, dari total 24 isolat yang berhasil diisolasi. Pada paper ini akan dilaporkan hasil identifikasi spesies bakteri isolat 22 menggunakan teknik PCR - sekuensing gen 16S rRNA dan karakter pertumbuhan dan resistensi isolat 22 terhadap Hg. Dari hasil sekuensing 16S rRNA, diketahui bahwa isolat 22 sangat dekat kekerabatannya dengan spesies Stenotrophomonas maltophilia (identity $99 \%$ dan query covered $90 \%$ ). Isolat 22 tumbuh dengan baik pada medium NB-Hg dengan kadar Hg 50 dan 100 ppm. Semakin tinggi kadar Hg dalam medum, semakin lama fase lag, walaupun jumlah sel pada medium di fase awal sama.
\end{abstract}

Kata kunci: isolat 22, hg, identifikasi, sekuensing, gen 165 rRNA

\section{PENDAHULUAN}

Keanekaragaman mikroba pada habitat ekstrim selalu menarik untuk dipelajari. Beberapa contoh habitat ekstrim yang hingga kini tetap dieksplorasi misalnya lingkungan bertemperatur dan bertekanan tinggi, habitat anoksik, dan habitat tercemar polutan. Habitat tercemar polutan tetap dihuni oleh mikroba aktif meskipun kadar polutan tinggi. Mikroba aktif tersebut biasanya adalah kelompok Archaea atau Bacteria (Barkay et al., 2003).

Kehidupan bakteri dan detoksifikasi senyawa polutan sangat berkaitan erat. Peran berbagai bakteri dalam detoksifikasi polutan sudah banyak dilaporkan dalam bentuk artikel tinjauan (review), baik untuk polutan logam berat maupun senyawa organik. Mekanisme seluler bakteri dalam menghadapi logam berat dapat dengan cara resistensi atau dengan cara biomineralisasi, sedangkan untuk polutan organik adalah dengan biodegradasi (Wang et al., 2020). Seringkali kemampuan detoksifikasi logam berat dan biodegradasi senyawa organik muncul bersama dari suatu sel bakteri, khususnya apabila di habitat bakteri tersebut tercemar logam berat dan senyawa organik secara bersamaan. Mendapatkan isolat bakteri-bakteri seperti ini sangat menguntungkan dari sudut pandang bioremediasi lingkungan (Gregoire et al., 2021).

Mikroba di habitat tercemar, khususnya bakteri, mampu beradaptasi menghadapi senyawa pencemar. Bahkan bakteri-bakteri merupakan sumber daya alami untuk membersihkan lingkungan tercemar. Identifikasi dan karakterisasi sifat-sifat bakteri-bakteri tersebut diperlukan agar upaya remediasi mikrobial dapat dioptimalkan (Setiabudi, 2005; Widiyanti et al., 2011). Strategi identifikasi bakteri dengan mensekuen gen 16 S rRNA saat ini merupakan metode standar namun karakterisasi sifat-sifat unggul bakteri tetap hanya dapat dilakukan dengan metode kultivasi (Devereux \& Wilkinson, 2004). Pada penelitian sebelumnya telah berhasil didapatkan 24 isolat bakteri dari limbah pertambangan logam (tailing), dari 24 isolat tersebut ditemukan bahwa isolat dengan kode 22 mampu bertahan hidup pada medium 
dengan kadar Merkuri (Hg) sebesar 100 ppm (Wiyono, 2015). Artikel ini melaporkan hasil identifikasi isolat 22 dengan metode PCR dan sekuensing gen $16 \mathrm{~S}$ rRNA.

\section{METODE}

\section{Pertumbuhan dan Resistensi Merkuri Isolat 22}

Secara aseptik isolat 22 ditumbuhkan dan disubkultur pada Nutrient Agar dengan kadar $\mathrm{Hg}\left(\mathrm{HgCl}_{2}\right.$, Merck) $100 \mathrm{ppm}$ dan diinkubasi pada suhu ruang selama 24-72 jam. Koloni tunggal isolat 22 yang mampu tumbuh pada medium NA-Hg (Nutrient Agar, Himedia) lalu diuji pertumbuhan dan resistensinya di medium NB $20 \mathrm{ml}$ (Nutrient Broth, Himedia, 8 gram per L) dengan kadar $\mathrm{Hg}\left(\mathrm{HgCl}_{2}\right) 100 \mathrm{ppm}$ dan medium yang sama tanpa $\mathrm{Hg}$ sebagai kontrol. Isolat 22 diamati pola pertumbuhannya (peningkatan kekeruhan sel pada OD600) dan diukur laju pertumbuhan selnya. Botol pertumbuhan diinkubasi pada suhu $37^{\circ} \mathrm{C}$ pada shaker inkubator dengan kecepatan putaran $150 \mathrm{rpm}$.

Pengambilan sampel dilakukan tiap satu jam sekali untuk kontrol dan dua jam sekali untuk sampel pada NB yang mengandung $\mathrm{Hg}$, hingga absorbansi densitas sel tidak menunjukkan kenaikan signifikan yang menunjukkan sel berada pada fase stasioner. Kultur dipanen sebanyak $150 \mu \mathrm{l}$ dan dimasukkan ke dalam sumur-sumur microplate untuk diukur ODnya pada panjang gelombang $600 \mathrm{~nm}$ dengan microplate reader. Data yang didapat berupa absorbansi, yang kemudian dapat dibuat kurva pertumbuhan dengan sumbu $\mathrm{x}$ adalah waktu inkubasi dan sumbu y adalah absorbansi. Selain itu juga dihitung laju pertumbuhan spesifik isolat 22 pada media pertumbuhan masing-masing.

\section{Identifikasi Spesies Isolat 22}

Isolat bakteri terpilih diekstraksi DNA kromosom-nya (Wizard Genomic DNA Purification Kit, Promega) dan dicek hasil isolasinya secara elektroforesis pada agarose $1 \%$ (Amresco) yang mengandung Etidium Bromida (Roche), kemudian dilakukan amplifikasi gen 16S rRNA menggunakan primer universal gen 16S rRNA (reverse 5'GTGAAGCTTACGGYTAGCTTGTTACGACTT-3' dan forward 5' CACGGATCCAGACTTTGATYMTGGCTCAG-3', First Base). Volume reaksi PCR sebesar $50 \mu$ yang terdiri dari $25 \mu \mathrm{l}$ GoTaq Green (Promega) Master Mix 2X, $5 \mu \mathrm{l}$ primer Forward $16 \mathrm{~S} 10 \mu \mathrm{M} / \mu \mathrm{l}, 5$ $\mu \mathrm{l}$ primer Reverse $16 \mathrm{~S} 10 \mu \mathrm{M} / \mu \mathrm{l}, 2,5 \mu \mathrm{l}$ DMSO (Sigma-Aldrich), DNA template $(0,5 \mathrm{ng} / \mu \mathrm{l})$, dan ddH2O yang dicampur di dalam tabung PCR, lalu diresuspensi agar homogen. Kontrol negatif dibuat dengan mencampurkan semua reagen yang digunakan kecuali DNA template. Amplikon dipurifikasi (PCR Cleanup Promega) dan dicek secara elektroforesis dengan menyertakan Marker DNA $1 \mathrm{~Kb}$ (Hyperladder Bioline) ketika elektroforesis.

Amplikon gen $16 S$ rRNA yang didapat dikirim ke Macrogen Inc., Korea untuk proses sekuensing. Sekuen yang didapatkan dari hasil sekuensing dibandingkan dengan database DNA pada NCBI (www.ncbi.nih.nlm.gov) menggunakan nucleotide BLAST dan membuat pohon filogenetik untuk mengetahui kekerabatan dengan bakteri lainnya.

HASIL

\section{Pertumbuhan dan Resistensi Merkuri Isolat 22}

Pada kurva pertumbuhan (Gambar 1) dapat dilihat bahwa semakin besar kadar $\mathrm{Hg}$ pada media maka semakin panjang fase lag bakteri isolat 22. Dari kurva pertumbuhan, juga dapat dihitung laju pertumbuhan spesifik isolat 22 . Secara umum waktu yang dibutuhkan isolat 22 untuk tumbuh pada media $\mathrm{Hg}$ adalah antara 24-36 jam. Pertumbuhan pada medium tanpa $\mathrm{Hg}$ dengan pada medium $\mathrm{Hg}$ berkadar 50 ppm berpola hampir sama. Hal ini berbeda dengan pertumbuhan $\mathrm{Hg}$ berkadar 100 ppm yang menunjukkan pola waktu adaptasi yang cukup lama.

Nilai laju pertumbuhan isolat 22 ketika tumbuh pada medium tanpa $\mathrm{Hg}$ berbeda dengan ketika tumbuh pada medium dengan $\mathrm{Hg}$. Laju pertumbuhan tertinggi tercapai ketika isolat 22 ditumbuhkan pada medium tanpa penambahan $\mathrm{Hg}$. Laju pertumbuhan menurun ketika $\mathrm{Hg}$ ditambahkan dengan kadar 50 ppm dan 100 ppm. 


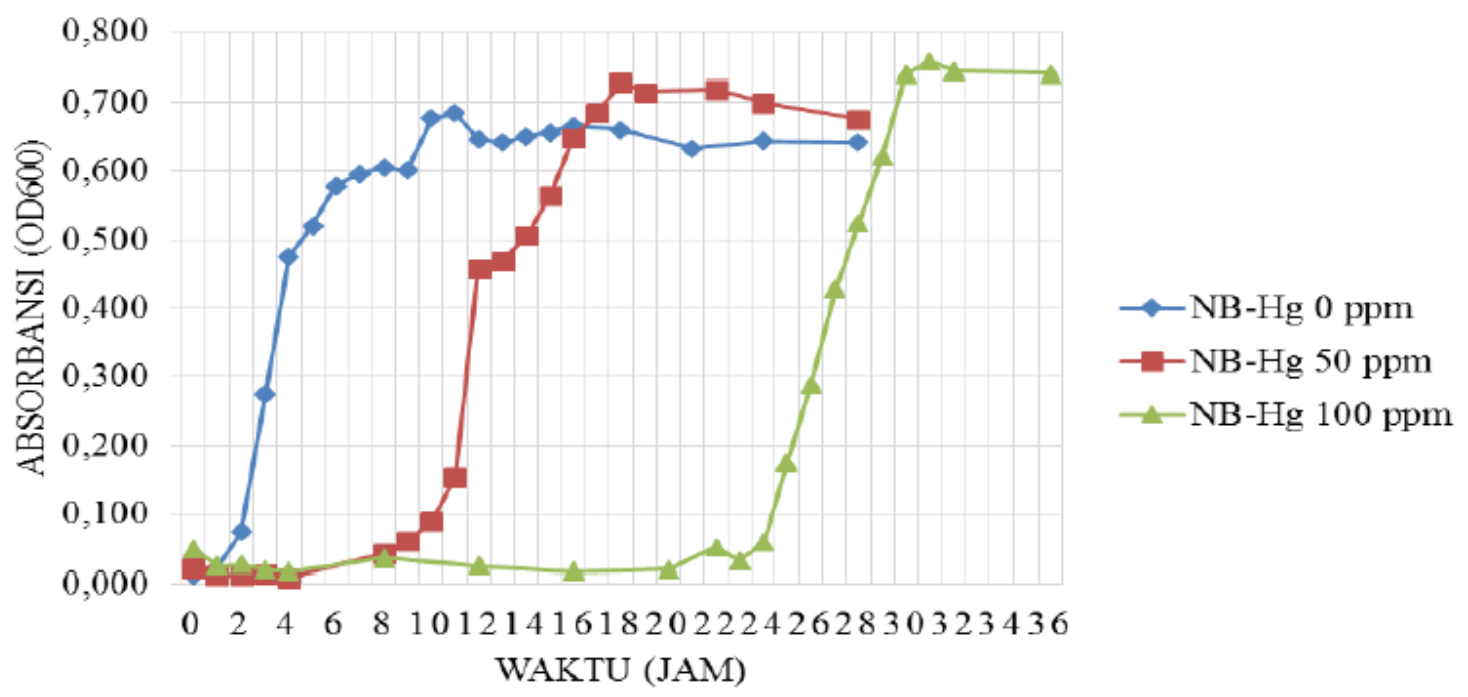

Gambar 1. Pola pertumbuhan isolat 22 pada medium NB dengan konsentrasi Hg berbeda (kondisi aerob, suhu $37^{\circ} \mathrm{C}$, kecepatan putaran $150 \mathrm{rpm}$ ).

Dari Tabel 1 dapat dikatakan bahwa semakin besar konsentrasi Hg dalam media, maka semakin turun laju pertumbuhan spesifik isolat 22. Dengan kata lain, waktu untuk mencapai fase eksponensial semakin panjang dan pertumbuhan bakteri tersebut terhambat (Dash \& Dash, 2012; Wiyono, 2015).

Tabel 1

Laju Pertumbuhan Isolat 22 Pada Medium NB-Hg 0, 50, 100 ppm (Kondisi Aerob, Suhu $37^{\circ} \mathrm{C}$, Kecepatan Putaran 150 rpm)

\begin{tabular}{ccc}
\hline No & $\begin{array}{c}\text { Konsentrasi Hg } \\
(\mathrm{ppm})\end{array}$ & $\begin{array}{c}\text { Laju } \\
\text { Pertumbuhan, } \\
\boldsymbol{\mu}\left(\text { jam }^{-1}\right)\end{array}$ \\
\hline 1 & 0 & 18 \\
2 & 50 & 13 \\
3 & 100 & 12 \\
\hline
\end{tabular}

Identifikasi Spesies Isolat 22

Amplifikasi gen 16S rRNA dari DNA genom bakteri dilakukan dengan PCR menggunakan primer universal untuk gen 16S rRNA. Hasil amplikon yang didapatkan kemudian dielektroforesis dan didapatkan pita berukuran sekitar $1.5 \mathrm{~kb}$ (Gambar 2).

Dari hasil sekuensing yang dilakukan pada amplikon PCR gen 16S rRNA isolat 22, didapatkan hasil urutan sekuen sepanjang 1485 bp (Gambar 3). Dari hasil BLAST pada NCBI dan pohon filogenetiknya (Gambar 4), diketahui bahwa isolat 22 berkerabat dekat dengan Stenotrophomonas maltophilia strain G7 dengan nilai query cover sebesar $90 \%$, nilai identity sebesar $99 \%$ dan $E$ value $=0$. Berdasarkan dari hasil BLAST dapat dikatakan bahwa isolat bakteri 22 kemungkinan besar merupakan Stenotrophomonas maltophilia. 


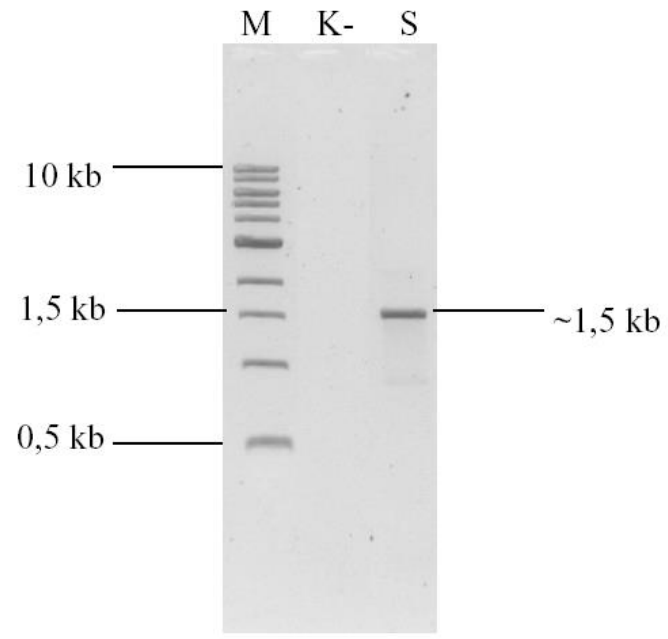

Gambar 2. Hasil amplifikasi gen $16 \mathrm{~S}$ rRNA isolat 22 dengan ukuran amplikon $1.5 \mathrm{~kb}$.

1 tTCACCCCAG tCATCGgCCA CaCCGTgGCA agCGCCCTCC CGaAgGtTAG GCTACCTGCT

61 TCTGGTGCAA CAAACTCCCA TGGTGTGACG GGCGGTGTGT ACAAGGCCCG GGAACGTATT

121 CACCGCAGCA ATGCTGATCT GCGATTACTA GCGATTCCGA CTTCATGGAG TCGAGTTGCA

181 GACTCCAATC GGGACTGAGA TAGGGTTTCT GGGATTGGCT TACCGTCGCC GGCTTGCAGC

241 CCTCTGTCCC TACCATTGTA GTACGTGTGT AGCCCTGGCC GTAAGGGCCA TGATGACTTG

301 ACGTCATCCC CACCTTCCTC CGGTTTGTCA CCGGCGGTCT CCTTAGAGTT CCCACCATTA

361 CGTGCTGgCA aCtaAgGaCA AGgGtTgCGC tCGTtGCGgG aCtTAaCCCA ACATCTCACG

421 ACACGAGCTG ACGACAGCCA TGCAGCACCT GTGTTCGAGT TCCCGAAGGC ACCAATCCAT

481 CTCTGGAAAG TTCTCGACAT GTCAAGGCCA GGTAAGGTTC TTCGCGTTGC ATCGAATTAA

541 ACCACATACT CCACCGCTTG TGCGGGCCCC CGTCAATTCC TTTGAGTTTC AGTCTTGCGA

601 CCGTACTCCC CAGGCGGCGA ACTTAACGGG TTAGCTTCGA TACTGCGTGC CAAATTGCAC

661 CCAACATCCA GTTCGCATCG TTTAGGGCGT GGACTACCAG GGTATCTAAT CCTGTTTGCT

721 CCCCACGCTT TCGTGCCTCA GTGTCAATGT TGGTCCAGGT AGCTGCCTTC GCCATGGATG

781 TTCCTCCTGA TCTCTACGCA TTTCACTGCT ACACCAGGAA TTCCGCTACC CTCTACCACA

841 TTCTAGTCGC TCAGTATCCA CTGCAGTTCC CAGGTTGAGC CCAGGGCTTT CACAACGGAC

901 TTAAACGACC ACCTACGCAC GCTTTACGCC CAGTAATTCC GAGTAACGCT TGCACCCTTC

961 GTATTACCGC GGCTGCTGGC ACGAAGTTAG CCGGTGCTTA TTCTTTGGGT ACCGTCATCC

1021 CAACCGGGTA TTAACCAGCT GGATTTCTTT CCCAACAAAA GGGCTTTACA ACCCGAAGGC

1081 CTTCTTCACC CACGCGGTAT GGCTGGATCA GGCTTGCGCC CATTGTCCAA TATTCCCCAC

1141 TGCTGCCTCC GGTAGGAGTC TGGACCGTGT CTCAGTTCCA GTGTGGCTGA TCATCCTCTC

1201 AGACCAGCTA CGGATCGTCC CCTTGGTGGG CCTTTACCCC GCCAACTAGC TAATCCGAAA

1261 TCGGGTCATT CAATCGCGCA AGGGCCGAAA ATCCCCTGCT TTTCACCCGA GGGGCCGAAG

1321 GCCGGTATAG CGGAAAGTTG CCTCCTTTTT CCCACCCACC AGAAGATCTG CAGGATTTCT

1381 ACCCTGTCGG CTCATGCCCC CACAGAACAT CTTCCTTTGT TGGTTGCAAA CTAGTATGTT

1441 GGCCTCCCTA CGTTCCTTGG CTAGAAAAAA ACGTGTGCCT GATAT

Gambar 3. Hasil sekuensing gen $16 \mathrm{~S}$ rRNA isolat 22. 


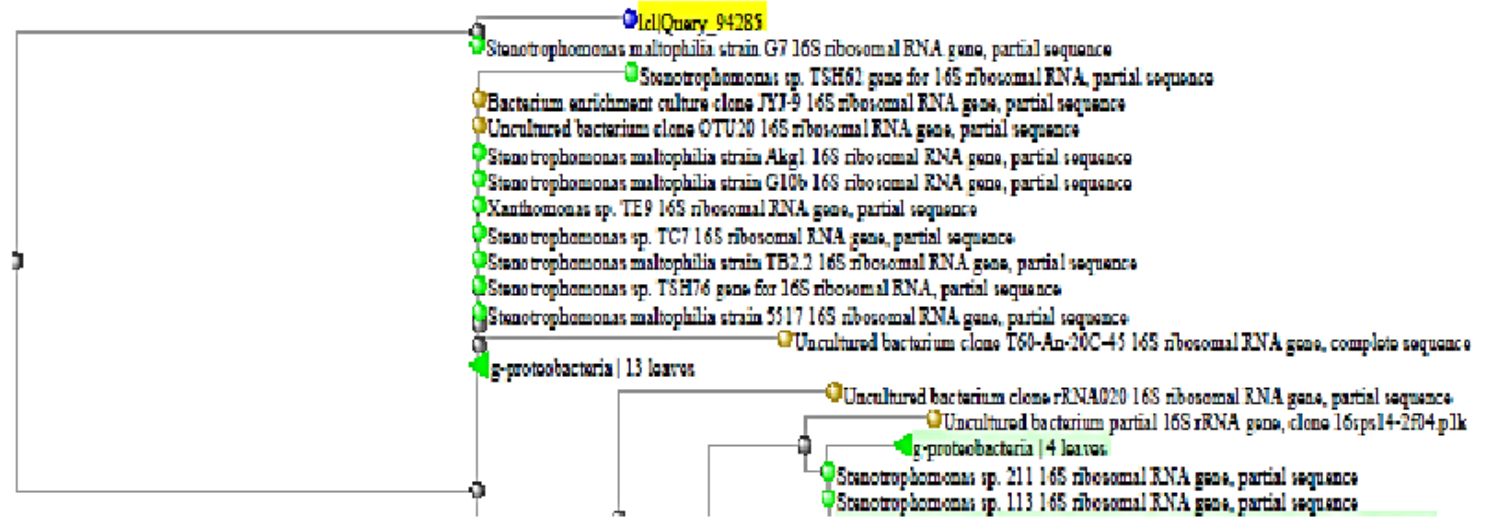

Gambar 4. Pohon kekerabatan sekuen gen 16S rRNA isolat 22 (BLAST-NCBI).

\section{BAHASAN}

Stenotrophomonas maltophilia mulai diteliti pada tahun 1966 oleh Stanier et al. dan termasuk dalam famili Xanthomonadaceae. Bakteri ini hingga tahun 1992 masih diperdebatkan apakah termasuk dalam genus Pseudomonas atau Xanthomonas. Akhirnya Palleroni dan Bradbury (1993) menggolongkan bakteri ini dalam genus baru, yaitu Stenotrophomonas. Berdasarkan pohon filogenetik isolat 22, Stenotrophomonas maltophilia strain G7 terdapat dalam cluster yang 87 sama dengan Xanthomonas sp., dan Pseudomonas sp. Hal ini membuktikan adanya kemiripan sifat Stenotrophomonas sp. dengan Xanthomonas sp., dan Pseudomonas sp. sehingga para peneliti jaman dahulu memperdebatkan golongan bakteri tersebut. Penelitian oleh Pages et al. (2008) menunjukkan bahwa Stenotrophomonas sp. sering ditemukan di tanah terutama rhizosphere tanaman. Selain itu, bakteri ini memiliki sifat resistensi terhadap beberapa jenis logam berat, yaitu tembaga, platinum, merkuri, emas, kadmium, timbal, kromium, perak, dan garam selenium (Pages et al., 2008).

Sampai saat ini, mekanisme resistensi Stenotrophomonas maltophilia terhadap $\mathrm{Hg}$ masih diteliti dan disebut terkait erat dengan sifat resistensi antibiotiknya. Kemungkinan Stenotrophomonas sp. memiliki karakteristik untuk mentransformasi $\mathrm{Hg}$ menjadi bentuk yang lebih tidak berbahaya (Pages et al., 2008) yaitu bentuk elemennya $\left(\mathrm{Hg}^{\circ}\right)$ oleh mer operon yang terdapat pada transposon, plasmid, ataupun kromosom bakteri. Operon ini memiliki banyak fungsi gen disamping gen peregulasinya. merT dan merP mengkode dua transporter yang bertanggung jawab untuk mengangkut $\mathrm{Hg}^{2+}$ ke dalam sitoplasma dan merA (mercuric ion reductase) akan mereduksi $\mathrm{Hg}^{2+}$ ke bentuk merkuri yang lebih tidak berbahaya $\left(\mathrm{Hg}^{0}\right)$ dan nantinya akan terdifusi keluar dari sel melalui membran sel (Stenzler, 2017; Roane \& Pepper, 2000).

Menurunnya laju pertumbuhan bakteri yang resisten akan keberadaan logam berat saat berada pada kondisi terpapar oleh logam berat tersebut dikarenakan pada kondisi tersebut sel bakteri menghadapi toksisitas logam $\mathrm{Hg}$ dan berusaha mendetoksifikasinya. Medium yang mengandung $\mathrm{Hg}$ merupakan kondisi pertumbuhan yang stres bagi sel bakteri yang resisten akan keberadaan $\mathrm{Hg}$ (Nascimento et al., 2003; Pages et al., 2008).

\section{SIMPULAN}

Berdasarkan hasil penelitian identifikasi isolat 22 melalui hasil sekuensing gen $16 \mathrm{~S}$ rRNA, menunjukkan bahwa isolat ini paling dekat kekerabatannya dengan Stenotrophomonas maltophilia strain G7 (identity 99\% dan query covered 90\%). Profil pertumbuhan isolat 22 pada media dengan kadar logam merkuri (II) 50 dan 100 ppm sangat baik. Semakin tinggi konsentrasi merkuri pada media, semakin lama fase lag/adaptasinya walaupun jumlah sel dalam media tetap. 


\section{PUSTAKA ACUAN}

Barkay, T., Miller, S.M., dan Summers, A.O. 2003. Bacterial mercury resistance from atoms to ecosystems. Elsevier. FEMS Microbiology Review 27, 355-384

Dash, H. R. dan Das, S. 2012. Bioremediation of Mercury and the Importance of Bacterial mer Genes. International Journal of Biodeterioration and Biodegradation 75, 207-213.

Devereux, R., dan Wilkinson, S. S. 2004. Amplification of Ribosomal RNA Sequences. Molecular Microbial Ecology Manual, Second Edition 3.01,

Gregoire, D.S, Janssen, S.E., Lavoie, N.C., Tate, M.T. dan Poulain, A.J. 2021. Stable isotope fractionation reveals similar atomic level control during aerobic and anaerobic microbial $\mathrm{Hg}$ transformation pathways. Applied and Environmental Microbiology 87 (18)

Huang, C. C., Chien, M. F., Lin, K. H. 2010. Bacterial mercury resistance of TnMER1 and its application in bioremediation. Enviromental Chemistry 3, pp. 23-29.

Nascimento, A. dan Chartone-Souza, E. 2003. Operon mer: bacterial resistance to mercury and potential for bioremediation of contaminated enviroments. Genetics and Molecular Research 2, 92-101.

Pages, D., Rose, J, Conrod, S, Cuine, S, Carrier, P, Heulin, T and Achouak, W. 2008. Heavy metal tolerance in Stenotrophomonas maltophilia. PLoS One 3(2): 1539

Palleroni, N.J and Bradbury, J.F. 1993. International Journal of Systematic Bacteriology 43, 606609

Roane, M. T. dan Pepper, I. 2000. Microorganism and Metal Pollution in Enviromental Microbiology. London: Academic Press.

Setiabudi, B. T. 2005. Penyebaran Merkuri Akibat Usaha Pertambangan Emas di Daerah Sangon, Kabupaten Kulon Progo, D. I. Yogyakarta. Kolokium Hasil Lapangan-DIM.

Stenzler, B, Hinz, A, Ruuskaden, M. dan Poulain, A.J. 2017. Ionic strength differentially affects the bioavailability of neutral and negatively charged ionic $\mathrm{Hg}$ complexes. Environmental Science and Technology 51, 9653-9662

Wang, Y, Janssen, S.E., Schaefer, J.K, Yee, N, dan Reinfelder, J.R. 2020. Tracing the uptake of $\mathrm{Hg}$ (II) in an Iron reducing bacterium using mercury stable isotope. Environmental Science and Technology Letter 7, 573-578

Widiyanti, A., Maya S., Nengah Dwianita K. 2011. Isolasi Dan Karakterisasi Bakteri Resisten Merkuri Di Hilir Kali Mas Surabaya. Surabaya: Fakultas Matematika dan Ilmu Pengetahuan Alam, Institut Teknologi Sepuluh Nopember Surabaya.

Wiyono, C. D. A. P. 2015. Isolasi Gen Pengkode Enzim Pereduksi Logam Merkuri. Skripsi. Universitas Surabaya. Surabaya. 